\title{
ANALYSIS OF SOCIO-ECONOMIC IMPACT OF ADVANCES ON BENEFICIARIES OF UNION BANK OF INDIA
}

\author{
Dr. (Smt.) Rajeshwari M. Shettar \\ Associate Professor, Department of Commerce \\ Shri Hurakadli Ajja Shikshana Samiti's \\ Smt. K. S. Jigalur Arts and Dr. (Smt.) S. M. Sheshgiri \\ Commerce College for Women, DHARWAD-8. \\ Behind Sahitya Bhavan Near R. N. Shetty Stadium, DHARWAD-8.
}

\begin{abstract}
The present study is a modest attempt to analyze the socio-economic impact of bank advances on beneficiaries. Beneficiaries were selected from Union Bank of India's branches at Dharwad District. The sample size of 300 beneficiaries was selected on the basis of stratified random sampling method. Data was processed and tabulated using Microsoft Excel-2007 software, then the data were analyzed with reference to the objectives and hypothesis by using differential analysis like chi-square test, unpaired t-test and one way ANOVA by using SPSS 16.0 statistical software and the results are obtained. The study found that, there has been a considerable change in the net income of the beneficiaries from advances. The results shows that, there has been a considerable increase in the income level, assets, status, employment, level of education, number of earning members in the family and the like. The study also reveals that, there is a positive socio-economic impact of advances on beneficiaries.
\end{abstract}

Key words: Beneficiaries, Advances, Socio-Economic Impact,

\section{Introduction:}

Banks are the heart of financial system. Banks play an important role in the economic development of the country. Dr. A.P.J. Abdul Kalam's vision of Indian Banks is that, "All banks should be a common man's bank: to offer all financial products and services to all its customers under one roof, at affordable cost in a fair and transparent manner". Corporate financial services, retail financial services and agricultural financial services are the main three areas of businesses of U B I. The loan products under corporate financial services include term loans for project funding, the creation or improvement of assets, short-term loans, cash credit, export credit, other working capital financing, and trade related products. Under retail financial services, bank provides retail advances for housing, retail trade, automobile, consumer goods, education and other personal loans. As part of the agricultural financial services, bank provides short and medium-term finances for agricultural activities, including crop loans, union green cards, advances for plantation, horticulture, fisheries, animal husbandry, beekeeping, sericulture and for allied activities like dairy and poultry. Bank also provides other services like distribution of global debit cards and global credit cards. In the Globalized scenario of banking, besides making profit; social responsibility is also one of the prime agenda of Commercial Banks. The country cannot progress unless and until the basic infrastructure facilities reach to each and every citizen of the country.

\section{Union Bank Of India: A Profile}

Union Bank of India completed 94 eventful years of service. Over these years, the bank cares for the common man. The bank was originally incorporated in Mumbai as the "The Union Bank of India Limited" under the companies act 1913, on November 11, 1919. After Nationalization, the name of the bank was changed to "Union Bank of India". From the beginning, bank had reached Himalayan heights, now ranked third among the nationalized banks. Its branches spread all over the country and serving for more than 26 million customers. For over nine decades, bank always put the customer before all else and made him the centre of our universe. On the technology front the bank has taken early initiatives and $100 \%$ of its branches are computerized.

Johanna Hietalahti and Mikeael Linden (2006) ${ }^{1}$

\section{Review Of Literature:}

In the study entitled "Socio-Economic impacts of microfinance and repayment performance: a case study of the Small Enterprise Foundation, South Africa". The researcher makes an attempt to study the socioeconomic impacts of microcredit's on women's welfare. The study focuses particularly on the benefits, disadvantages and challenges obtained from the Small Enterprise Foundation (SEF), micro credit village programmes, and Micro Credit Programme (MCP) and the Tshomisano Credit Programme (TCP). Impacts of 
microcredit's and a comparison of two programmes were analyzed on household level. The study revealed that, the poorest women have been released from deepest poverty through the opportunities provided by Small Enterprise Foundation (SEF).

\section{Dr. Rakesh Mohan (2006)}

In the study entitled "Impact of Low Rate of Interest on Rural Credit-A Case Study". The researcher explores the impact of Government scheme of cheaper credit on rural farmers. The study was carried out in eight selected districts like Bidar, Bijapur, Chikmangalure, Dharwad, Mysore, Raichur, Shimoga and Tumkur districts, covering 33 talukas and 33 Primary Agricultural Cooperative Credit Societies (PACS). The study covered a beneficiary survey of 2577 borrowers in these PACS. The study found that, the scheme has made significant impact on the recovery of overdue loans at Primary Agricultural Cooperative Credit Societies level.

Shiralshetti A. S. (2005) ${ }^{3}$

In the study entitled "Bank finance for Grape Cultivation in Bijapur District: A Diagnostic Study". The study deals with bank finance for grape cultivation in Bijapur district. The study was to analyze the socioeconomic impact on grape cultivators in the district. 450 sample grape cultivators and 41 officers from commercial banks, 21 officers from regional rural banks and 14 officers from co-operative banks were selected for the study. The study signifies that, male sex dominates the female in the grape cultivation. The study found that, joint family system had more scope to take grape cultivation due to its labour intensive nature.

Rajashekar Hurkadli (2002)

In the study entitled "Bank Finance to Sugarcane Growers in Belgaum District: A Critical Study". The study deals with the bank finance i.e. lending practices like credit disbursement, estimation of cost of credit, its utilization, overdue problems, recovery practices and problems faced by sugarcane growers in obtaining loan from banks. Various statistical tools like SPSS (1993), STATISTICA (1985) statistical packages, trend analysis, T-test, ANOVA, regression analysis were used. The study found that, the income of all farmers is increasing in the post-loan period. The study also found that, the increment in income of borrowers has a positive impact of bank finance on sugarcane grower's income. The economic impact of bank loan was positive indicator towards development.

\section{Objectives Of The Study:}

1. To study the Socio-Economic Impact of Bank Finance on Beneficiaries.

2. To offer useful Suggestions for the better Management of Finance.

Area Of The Study:

Union Bank of India branches at Dharwad District is selected for the present study.

\section{Methodology Of The Study:}

A sample size of 300 beneficiaries of UBI branches at Dharwad District was selected. The sample beneficiaries were selected on the basis of stratified random sampling method. Collected data through interview schedule and conducted personal interview for beneficiaries. Data was processed and tabulated using Microsoft Excel - 2007 Software. Then the data was analyzed by using differential analysis like chi-square test, unpaired t-test and one way ANOVA by using SPSS 16.0 statistical software and the results are obtained.

\section{Analysis Of The Impact Of Advances:}

H 1:Testing the Significance of association between levels of impact of Bank advances on beneficiaries and different Socio-Economic characteristics of beneficiaries.

Null Hypotheses $\left(\mathbf{H}_{\mathbf{0}}\right)$ : There is no significant association between levels of impact of Bank advances on beneficiaries and different Socio-Economic characteristics of beneficiaries.

Alternative Hypotheses $\left(\mathbf{H}_{1}\right)$ : There is significant association between levels of impact of Bank advances on beneficiaries and different Socio-Economic characteristics of beneficiaries.

To achieve this hypothesis, the chi-square test is applied and the results are presented in the following table.

Table 1.1: Association between Levels of Impact with Customer's Different Factors

\begin{tabular}{|c|c|c|c|c|c|c|c|c|c|}
\hline \multirow{2}{*}{$\begin{array}{c}\text { Different } \\
\text { Characteristics }\end{array}$} & \multicolumn{7}{|c|}{ Levels of Socio-Economic Impact on Beneficiaries } & \multirow{2}{*}{$\begin{array}{l}\text { Chi- } \\
\text { Square }\end{array}$} & \multirow{2}{*}{ P-Value } \\
\hline & Low & $\%$ & Average & $\%$ & High & $\%$ & Total & & \\
\hline \multicolumn{10}{|c|}{ Location of Residence } \\
\hline Urban & 69 & 39.88 & 39 & 22.54 & 65 & 37.58 & 173 & \multirow[t]{2}{*}{2.7918} & \multirow[t]{2}{*}{0.2476} \\
\hline Rural & 58 & 45.67 & 33 & 25.98 & 36 & 28.35 & 127 & & \\
\hline \multicolumn{10}{|l|}{ Age groups } \\
\hline$<20$ years & 7 & 41.18 & 6 & 35.29 & 4 & 23.53 & 17 & 18.7580 & $0.0435^{*}$ \\
\hline
\end{tabular}


Analysis Of Socio-Economic Impact Of Advances On Beneficiaries Of Union ...

\begin{tabular}{|c|c|c|c|c|c|c|c|c|c|}
\hline $21-30$ years & 11 & 40.74 & 5 & 18.52 & 11 & 40.74 & 27 & & \\
\hline $31-40$ years & 28 & 41.18 & 22 & 32.35 & 18 & 26.47 & 68 & & \\
\hline $41-50$ years & 44 & 36.07 & 29 & 23.77 & 49 & 40.16 & 122 & & \\
\hline 51-60years & 22 & 48.89 & 6 & 13.33 & 17 & 37.78 & 45 & & \\
\hline$>60$ years & 15 & 71.43 & 4 & 19.05 & 2 & 9.52 & 21 & & \\
\hline \multicolumn{10}{|l|}{ Gender } \\
\hline Male & 108 & 47.58 & 53 & 23.35 & 66 & 29.07 & 227 & \multirow[t]{2}{*}{12.0669} & \multirow[t]{2}{*}{$0.0024^{*}$} \\
\hline Female & 19 & 26.03 & 19 & 26.03 & 35 & 47.94 & 73 & & \\
\hline \multicolumn{10}{|l|}{ Castes } \\
\hline $\mathrm{SC}$ & 16 & 32.00 & 16 & 32.00 & 18 & 36.00 & 50 & \multirow[t]{4}{*}{14.9317} & \multirow[t]{4}{*}{ 0.0208* } \\
\hline ST & 7 & 25.93 & 4 & 14.81 & 16 & 59.26 & 27 & & \\
\hline OBC & 16 & 55.17 & 8 & 27.59 & 5 & 17.24 & 29 & & \\
\hline GM & 88 & 45.36 & 44 & 22.68 & 62 & 31.96 & 194 & & \\
\hline \multicolumn{10}{|l|}{ Literacy } \\
\hline Literates & 113 & 40.21 & 67 & 23.84 & 101 & 35.95 & 281 & \multirow[t]{2}{*}{11.5841} & \multirow[t]{2}{*}{$0.0031^{*}$} \\
\hline Illiterates & 14 & 73.68 & 5 & 26.32 & 0 & 0.00 & 19 & & \\
\hline \multicolumn{10}{|l|}{ Occupations } \\
\hline Agriculture & 40 & 39.22 & 30 & 29.41 & 32 & 31.37 & 102 & 35.5736 & 0.0004* \\
\hline Business & 36 & 45.00 & 13 & 16.25 & 31 & 38.75 & 80 & & \\
\hline Profession & 5 & 35.71 & 2 & 14.29 & 7 & 50.00 & 14 & & \\
\hline $\begin{array}{l}\text { Government } \\
\text { employee }\end{array}$ & 34 & 50.75 & 22 & 32.83 & 11 & 16.42 & 67 & & \\
\hline Self employee & 5 & 55.56 & 2 & 22.22 & 2 & 22.22 & 9 & & \\
\hline House wife & 2 & 28.57 & 3 & 42.86 & 2 & 28.57 & 7 & & \\
\hline Students & 5 & 23.81 & 0 & 0.00 & 16 & 76.19 & 21 & & \\
\hline \multicolumn{10}{|c|}{ Type of the Family } \\
\hline Joint family & 22 & 40.00 & 16 & 29.09 & 17 & 30.91 & 55 & \multirow[t]{2}{*}{0.9660} & \multirow[t]{2}{*}{0.6169} \\
\hline Nuclear family & 105 & 42.86 & 56 & 22.86 & 84 & 34.28 & 245 & & \\
\hline \multicolumn{10}{|l|}{ Size of the Family } \\
\hline$<3$ & 8 & 66.67 & 0 & 0.00 & 4 & 33.33 & 12 & \multirow[t]{4}{*}{18.4011} & \multirow[t]{4}{*}{$0.0053^{*}$} \\
\hline $3-6$ & 110 & 44.90 & 57 & 23.27 & 78 & 31.83 & 245 & & \\
\hline $6-9$ & 1 & 4.55 & 9 & 40.90 & 12 & 54.55 & 22 & & \\
\hline$>9$ & 8 & 38.10 & 6 & 28.57 & 7 & 33.33 & 21 & & \\
\hline \multicolumn{10}{|c|}{ Earning Members in the Family } \\
\hline One & 101 & 44.30 & 56 & 24.56 & 71 & 31.14 & 228 & \multirow[t]{4}{*}{15.0699} & \multirow[t]{4}{*}{$0.0197^{*}$} \\
\hline Two & 13 & 33.33 & 13 & 33.33 & 13 & 33.33 & 39 & & \\
\hline Three & 6 & 31.58 & 0 & 0.00 & 13 & 68.42 & 19 & & \\
\hline Four & 7 & 50.00 & 3 & 21.43 & 4 & 28.57 & 14 & & \\
\hline \multicolumn{10}{|c|}{ Purpose of Availing Loan } \\
\hline Agriculture & 47 & 39.17 & 34 & 28.33 & 39 & 32.50 & 120 & \multirow[t]{5}{*}{6.9874} & \multirow[t]{5}{*}{0.3220} \\
\hline $\begin{array}{l}\text { Micro Small and } \\
\text { Medium }\end{array}$ & 4 & 44.45 & 2 & 22.22 & 3 & 33.33 & 9 & & \\
\hline $\begin{array}{l}\text { Business / } \\
\text { Profession }\end{array}$ & 5 & 25.00 & 4 & 20.00 & 11 & 55.00 & 20 & & \\
\hline Retail advances & 71 & 47.02 & 32 & 21.19 & 48 & 31.79 & 151 & & \\
\hline Total & 127 & 42.33 & 72 & 24.00 & 101 & 33.67 & 300 & & \\
\hline
\end{tabular}

Source: Field Survey $* \mathrm{p}<0.05$

Table 1.1reveals that, Out of 300 beneficiaries, a maximum of 127 (42.33\%) beneficiaries belongs to low impact level followed by 101 (33.67\%) belongs to high impact level and $72(24.00 \%)$ belongs to level of average impact. But each characteristic wise distribution of beneficiaries are presented and explained in the above table and following points:

* Urban and rural beneficiaries have similar levels of socio-economic impact (chi-square $=2.7918, \mathrm{p}=0.2476$ ) at $5 \%$ level of significance. Hence, the null hypothesis is accepted. It means that, the location and levels of impact are not associated statistically. 
* A significant association was observed between the age groups of beneficiaries and levels of socioeconomic impact (chi-square $=18.7580, \mathrm{p}=0.0435$ ) at $5 \%$ level of significance. Hence, the alternative hypothesis is accepted. It means that, most of the beneficiaries belongs to lower age groups have low level of impact as compared to beneficiaries belongs to higher age groups.

* The $47.58 \%$ of male beneficiaries have lower level of socio-economic impact as compared to $47.94 \%$ female beneficiaries and which is found to be statistically significant (chi-square $=12.0669, \mathrm{p}=0.0024$ ) at 5\% level of significance. Hence, the alternative hypothesis is accepted. It means that, the gender and levels of impact are associated statistically.

* A significant association was observed between castes of beneficiaries and levels of socio-economic impact (chi-square=14.9317, $\mathrm{p}=0.0208$ ) at $5 \%$ level of significance. Hence, the alternative hypothesis is accepted. It means that, the SC and ST caste beneficiaries have higher level of impact as compared to OBC and GM caste beneficiaries.

* The $73.68 \%$ (14) illiterate beneficiaries have lower level of socio-economic impact as compared to $35.95 \%$ (101) literate beneficiaries have higher level of impact and which is found to be statistically significant (chi-square $=11.5841, \mathrm{p}=0.0031$ ) at $5 \%$ level of significance. Hence, the alternative hypothesis is accepted. It means that, the literacy and levels of socio-economic impact by advances are statistically associated.

* A maximum of $55.56 \%$ (5) self employee beneficiaries have lower level of socio-economic impact and minimum of $23.81 \%$ (5) of students beneficiaries have lower level of impact. However, a maximum of $76.19 \%$ (16) students beneficiaries have higher level of socio-economic impact and minimum of $16.42 \%$ (11) government employee beneficiaries have higher level of impact by advances. But, association is found to be statistically significant (chi-square $=35.5736, p=0.0004$ ) at $5 \%$ level of significance. Hence, the alternative hypothesis is accepted.

* The beneficiaries living in nuclear family and joint families have similar levels of socio-economic impact (chi-square $=0.9660, p=0.6169$ ) at $5 \%$ level of significance. Hence, the null hypothesis is accepted. It means that, the types of family and levels of impact are not associated.

* The $66.67 \%$ (8) beneficiaries living in less than 3 member size of family have lower level of socioeconomic impact and 54.55\% (12) beneficiaries living in the size of 6-9 member have higher level of impact (chi-square $=18.4011, \mathrm{p}=0.0053$ ) at $5 \%$ level of significance. Hence, the alternative hypothesis is accepted. It means that, the beneficiaries belong to different sizes of family have different levels of socioeconomic impact by advances.

* The $50.00 \%$ (7) beneficiaries living in 4 earning members in the family have lower level of socio-economic impact and $68.42 \%$ (13) beneficiaries living in 3 earning members in the family have higher level of impact by advances (chi-square $=15.0699, \mathrm{p}=0.0197$ ) at $5 \%$ level of significance. Hence, the alternative hypothesis is accepted. It means that, the beneficiaries living with different size of earning members in the family have different levels of impact by advances.

* Lastly, the beneficiaries took a loan for different purposes have similar levels of socio-economic impact (chi-square $=6.9874, p=0.3220$ ) at $5 \%$ level of significance. Hence, the null hypothesis is accepted. It means that, the purposes of availing loan and levels of impact are not associated. In another words, the levels of socio-economic impact are not depends on purposes of availing loan.

The details are presented in the above table and levels of socio-economic impact are presented in the following figure.

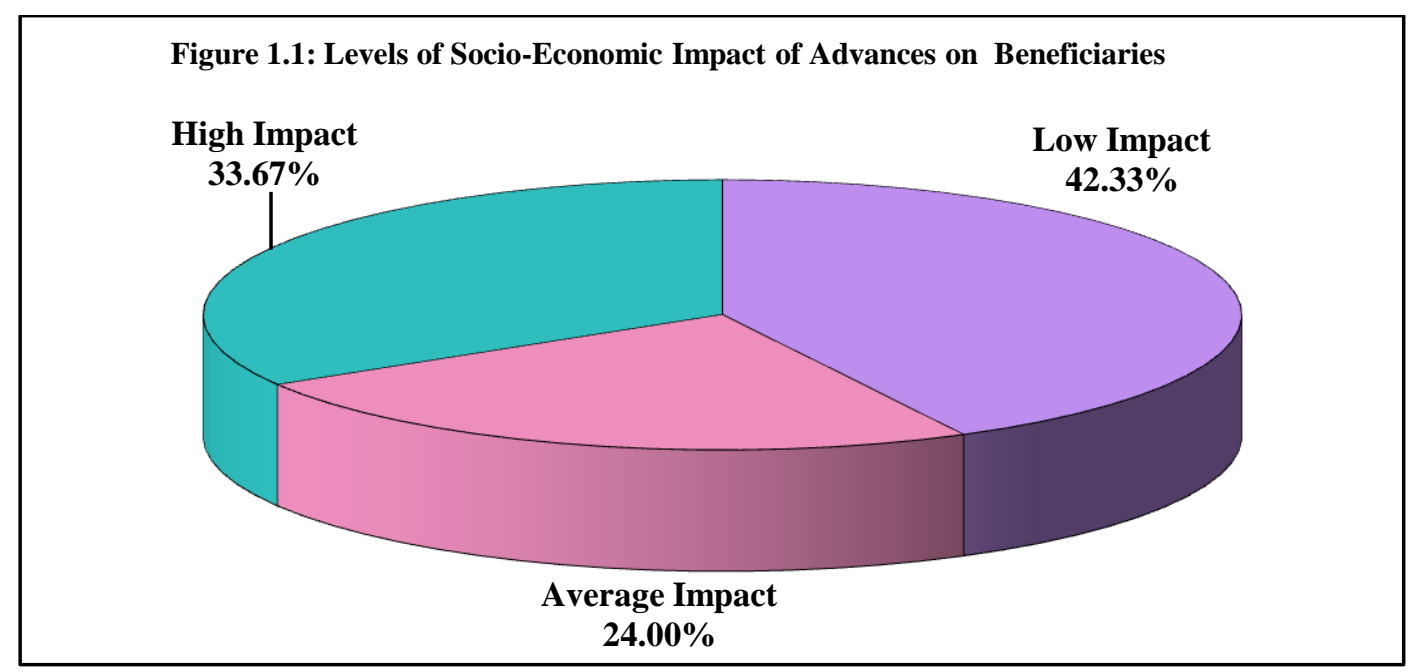


H 2: Testing the Significance of the relationship between the Total Impact and the different characteristics of beneficiaries.

Null Hypotheses $\left(\mathbf{H}_{\mathbf{0}}\right)$ : There is no significance of the relationship between the Total Impact and the different characteristics of beneficiaries.

Alternative Hypotheses $\left(\mathbf{H}_{1}\right)$ : There is significance of the relationship between the Total Impact and the different characteristics of beneficiaries.

To achieve this hypothesis, the Karla Pearson's correlation coefficient technique has been performed and the results are presented in the following table.

Table 1.2: Correlation Coefficients between Total Impact Scores with their different Characteristics

\begin{tabular}{|l|c|c|c|}
\hline Characteristics & Correlation Coefficient & t-value & p-value \\
\hline Location of Residence & -0.1482 & -2.5865 & $0.0102^{*}$ \\
\hline Age groups & -0.1464 & -2.5546 & $0.0111^{*}$ \\
\hline Gender & 0.2192 & 3.8776 & $0.0001^{*}$ \\
\hline Castes & -0.1133 & -1.9679 & $0.0500^{*}$ \\
\hline Education & -0.2173 & -3.8433 & $0.0001^{*}$ \\
\hline Occupations & 0.1718 & 3.0098 & $0.0028^{*}$ \\
\hline Types of family & 0.1189 & 2.0670 & $0.0396^{*}$ \\
\hline Size of the family & 0.0400 & 0.6905 & 0.4904 \\
\hline Earning members in the family & 0.0260 & 0.4483 & 0.6543 \\
\hline Purpose of availing loan & 0.0144 & 0.2489 & 0.8036 \\
\hline
\end{tabular}

Source: Field Survey $* \mathrm{p}<0.05$

From the results of the above table, it can be seen that,

* A significant and negative relationship was observed between locations of residence of beneficiaries and total impact scores $(\mathrm{r}=-0.1482, \mathrm{p}=0.0102)$ at $5 \%$ level of significance. Hence, the alternative hypothesis is accepted. It means that, the locations of residence of beneficiaries and total impact scores are dependent on each other.

* A significant and negative relationship was observed between age groups of beneficiaries and total impact scores $(\mathrm{r}=-0.1464, \mathrm{p}=0.0111)$ at $5 \%$ level of significance. Hence, the alternative hypothesis is accepted. It means that, the age groups of beneficiaries and total impact scores are dependent on each other.

* A significant and positive relationship was observed between gender of beneficiaries and total impact scores $(\mathrm{r}=0.2192, \mathrm{p}=0.0001)$ at $5 \%$ level of significance. Hence, the alternative hypothesis is accepted. It means that, the gender of beneficiaries and total impact scores are dependent on each other.

* A significant and negative relationship was observed between castes of beneficiaries and total impact scores $(\mathrm{r}=-0.1133, \mathrm{p}=0.0500)$ at $5 \%$ level of significance. Hence, the alternative hypothesis is accepted. It means that, the castes of beneficiaries and total impact scores are dependent on each other.

* A significant and negative relationship was observed between educational qualifications of beneficiaries and total impact scores $(\mathrm{r}=-0.2173, \mathrm{p}=0.0001)$ at $5 \%$ level of significance. Hence, the alternative hypothesis is accepted. It means that, the educational qualifications of beneficiaries and total impact scores are dependent on each other.

* A significant and positive relationship was observed between occupations of beneficiaries and total impact scores $(\mathrm{r}=0.1718, \mathrm{p}=0.0028)$ at $5 \%$ level of significance. Hence, the alternative hypothesis is accepted. It means that, the occupations of beneficiaries and total impact scores are dependent on each other.

* A significant and positive relationship was observed between types of family of beneficiaries and total impact scores $(\mathrm{r}=0.1189, \mathrm{p}=0.0396)$ at $5 \%$ level of significance. Hence, the alternative hypothesis is accepted. It means that, the types of family of beneficiaries and total impact scores are dependent on each other.

* A non-significant and positive relationship was observed between different sizes of family of beneficiaries and total impact scores $(\mathrm{r}=0.0400, \mathrm{p}=0.6905)$ at $5 \%$ level of significance. Hence, the null hypothesis is accepted. It means that, the different sizes of family of beneficiaries and total impact scores are not dependent on each other.

* A non-significant and positive relationship was observed between number of earning members in the family of beneficiaries and total impact scores $(\mathrm{r}=0.0260, \mathrm{p}=0.4483)$ at $5 \%$ level of significance. Hence, the null hypothesis is accepted. It means that, the number of earning members in the family of beneficiaries and total impact scores are not dependent on each other.

* A non-significant and positive relationship was observed between purpose of availing loan of beneficiaries and total impact scores $(\mathrm{r}=0.0144, \mathrm{p}=0.2489)$ at $5 \%$ level of significance. Hence, the null hypothesis is 
accepted. It means that, the purpose of availing loan of beneficiaries and total impact scores are not dependent on each other.

\section{Findings Of The Study:}

1. The urban beneficiaries have higher total impact and social impact as compared to rural beneficiaries, but urban and rural beneficiaries have similar economic impact.

2. The beneficiaries belong to different age groups have different total impact, economic impact and social impact by advances of U BI.

3. The location of residence, the age group, the gender, different castes, and the occupation of beneficiaries and total impact scores by advances of UBI are dependent on each other.

4. The educational qualifications, type of family, size of the family, earning members in the family, and the purpose of availing loan of beneficiaries and total impact scores by advances of UBI are not dependent on each other.

\section{Suggestions:}

1. UBI has to identify the clear purpose of the borrowers.

2. The bank has to reduce operational cost, enhance income and at the same time strengthen customer relationship.

3. Bank must concentrate and identify the core age group where the funds can be mobilized in an appropriate manner.

4. As our nation is a agricultural based more thrust must be given on the loan given to agriculture to bring more acreage of bare lands under cultivation.

5. Target the weaker sections of community and take the quicker action of implementation.

6. Bank has to concentrate in providing loans and convince to suggest illiterate beneficiaries.

\section{Conclusion:}

For over Nine decades the Union Bank of India have earned the reputation of being techno-savvy bank and is one of the front runners amongst public sector bank in the field of technology. With its prudent management and good governance, banks non-performing assets were comparatively lower. Bank is firmly committed to consolidating and maintaining its identity as a leading, innovative Commercial Bank, with a proactive approach to the changing needs of the society. This is because of number of products and services made available to its valuable customers. Today, with its efficient, value-added services, sustained growth, consistent profitability and development of new technologies, UBI has ensured complete customer delight, living up to its image of, "GOOD PEOPLE TO BANK WITH". The key to the success of any organization lies with its people. The Bank, as a good corporate citizen, has stepped into the arena of counseling the common man to help them and lead a decent and honorable life in the future days to come.

\section{References:}

[1]. Johanna Hietalahti and Mikael Linden "Socio-Economic impacts of microfinance and repayment performance: a case study of the Small Enterprise Foundation, South Africa", Journal of Progress in Development Studies, 6, 32006 pp 201-210.

[2]. Dr. Rakesh Mohan "Impact of Low Rate of Interest on Rural Credit-A Case Study", Financing Agriculture-A National Journal of Agriculture and Rural Development October-November, 2006.

[3]. A.S. Shiralshetti "Bank finance for Grape Cultivation in Bijapur district: A diagnostic study", A Ph d Thesis submitted to K. U. Dharwad, 2005.

[4]. Rajashekar Hurkadli "Bank Finance to Sugarcane Growers in Belgaum District: A Critical Study", A Ph.D. Thesis submitted to K.U. Dharwad, 2002.

[5]. Jothi V.N. "Socio-Economic Impact : Micro financing of Self Help Groups", SCMS Journal of Indian Management, January-March, 2010.

[6]. Debadutta Kumar Panda "Socio-Economic Impacts of Self-Help Groups on Rural Women: Findings from Orissa and Jharkhand States of India", ASBM Journal of Management, II(2), 2009.

[7]. Lokhande, M.A "Socio-economic impact of micro financing through self-help groups in Marathwada Region". The Indian Journal of Commerce 61(4), 2008 :151-164.

[8]. Websites: (a) www.rbi.org.in (b) www.unionbankofindia.com 